\title{
Aquaculture Monitoring and Control Systems for Seaweed and Fish Farming
}

\author{
Nitaigour Premchand Mahalik ${ }^{1, *}$, Kiseon Kim² \\ ${ }^{1}$ Department of Industrial Technology, Jordan College of Agricultural Sc and Technology, California State Univ., Fresno, USA \\ ${ }^{2}$ Department of Information and Communication, Gwangju Institute of Science and Technology, Gwangju, Republic of Korea \\ *Corresponding author: nmahalik@csufresno.edu
}

Received June 25, 2014; Revised August 08, 2014; Accepted August 15, 2014

\begin{abstract}
This paper reviews aquaculture monitoring and control systems for seaweed and fish farming. Seaweeds farming play an important role in business and constantly growing. Seaweed is considered to be second largest freshwater farming industry in the world. Not only seaweeds are eaten raw, but through industrial process, some components are extracted to use in other foods. This paper provides 5 types of seaweed species and their aquaculture methods that are very popular. Also we have reviewed, the per capita fish consumption (region-wise), global annual fish production, global fish production in past 60 years, fish production in percentage by region, global seaweed production, seaweed value and important seaweeds for industrial use. Implication of technology such as the Recirculating Aquaculture System (RAS) integrated with sensors, pumping system and filtering mechanism to measure, control and eradicate parameters, variables, and wastes developed by academic institution that has already been demonstrated was reviewed. Typical specification of a 4-tank based RAS is given. The paper also provides an advanced monitoring and control architecture that can be capable of automating precise production processes. Details about the control hardware such as sensors, motors, pumps, electronics, computer and software are presented.
\end{abstract}

Keywords: Aquaculture, automation and control, Recirculating System, monitoring, technology usage

Cite This Article: Nitaigour Premchand Mahalik, and Kiseon Kim, "Aquaculture Monitoring and Control Systems for Seaweed and Fish Farming." World Journal of Agricultural Research, vol. 2, no. 4 (2014): 176-182. doi: 10.12691/wjar-2-4-7.

\section{Introduction}

Food and Agriculture Organization (FAO) of the United Nations (UN) estimates that the world food productions need to be increased by $60 \%$ by 2050 to feed 9,000 million of inhabitants. Food security is threatened when people do not have physical and economic access to sufficient, safe and nutritious foods that meet dietary needs and preferences for an active and healthy life [1]. Food security depends upon the following factors: (1) availability: the availability of sufficient food quantities of appropriate quality; (2) access: access by individuals to adequate resources for acquiring appropriate foods for a nutritious diet on a regular basis; (3) utilization: utilization of food through clean water, sanitation, and health care to reach a nutritional well-being where all physiological needs are met; and (4) stability: a population or region must have access to food at all times and should not risk losing access as a consequence of sudden shocks or cyclical events.

Worldwide population growth combined with increased pressures on farm production outputs creates a market opportunity for world businesses on the supply, processing, and storage sides. Progress made in both agricultural production and food processing will contribute to a more secure food supply [2]. New methods and technology-based solutions are needed in agricultural production and food processing to increase the food production in the coming decades.

Sea provides us a good amount of food round the year. Two of the important foods are fish and seaweed. As a matter of fact, aquaculture based seafood farming has become a trend. Note that $60 \%$ of the world population lives with 60 kilometers from the sea. So, the seafood business has been impacting the local as well as global economy. As an example, Ireland established the Seafood Strategy Review Group (SSRG) to set out its vision for a sustainable, profitable and self-reliant industry for longterm contribution to coastal communities and a healthy and diverse marine environment. Innovative procedures are increasingly important to meet the growing demands of demographic and social developments as well as changing consumption patterns. Food security has been important in all the countries. The seafood farming is slow and poorly-paid, but aquaculture industry has been advanced to meet the demand.

\section{Review: Global Business Trends}

Seaweeds farming play an important role in business and constantly growing. Although aquatic farming has been more than a millennium long, but on the global scale it is still a young sector of food production and the world 
has seen significant growth since last 60 years. Seaweed is considered to be second largest freshwater farming industry in the world. With a global production of 7.5 million tons, aquaculture based seaweed farming will have significant impact on local economy. Seaweed consumption is more in second-world countries, but advances in intercontinental trades and increased migration, immigration, and visits have impacted the consumption in the first and third world countries. China is the largest producer of seaweed accounting for approximately 99 percent of total production. Figure 1 shows the review and global seafood business trends at a glance.

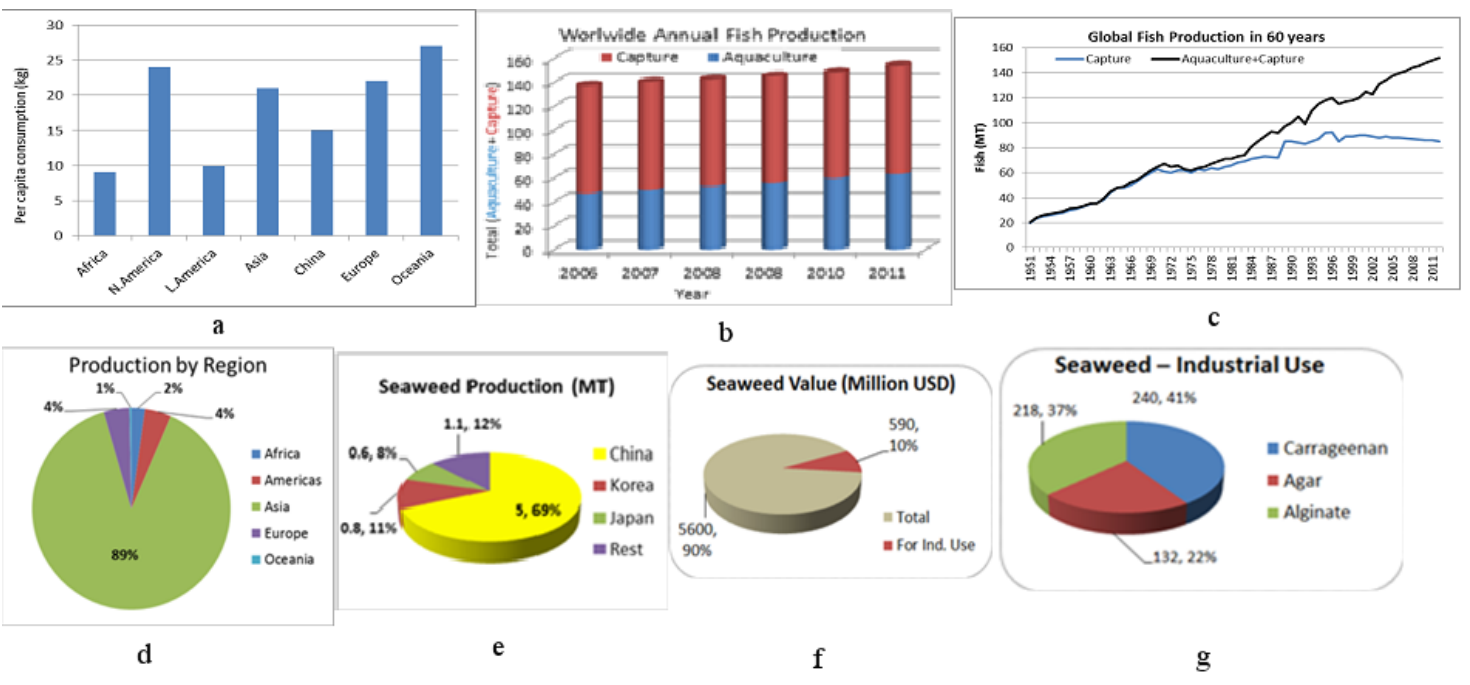

Figure 1. (a) Per capita fish consumption; (b) Global annual fish production (Top: Captured fish, Bottom: Aquaculture based); (c) Global fish production in past 60 years; (d) Fish production in percentage by region, (e) Global seaweed production (MT, \%), (f) Seaweed value ((USD in Million, \% use for food vs. industry use), (g) Three type of seaweeds for industrial use (Dollar value, \%) [3,4,5]

Table 1. Font Sizes for Papers

\begin{tabular}{|c|c|c|c|c|c|c|}
\hline Seaweed & $\begin{array}{c}\text { Biological } \\
\text { name(s) }\end{array}$ & Color & Nutrients & Suitable for cultivation & $\begin{array}{c}\text { Mostly } \\
\text { used }\end{array}$ & Image \\
\hline Nori & Porphyra spp & Purple & $\begin{array}{l}\text { 30-50\% protein; } 0.1 \% \text { sugar; High } \\
\text { vitamin A, C; Niacin and folic, } \\
\text { amino acid; Low NaCl; }\end{array}$ & $\begin{array}{c}\text { Floating system; shallow-water pole system; } \\
\text { can grow up to } 35 \mathrm{~cm} \text {; grown Oct-Nov; } \\
\text { Temp. } 5-12^{\circ} \mathrm{C} \text {. }\end{array}$ & $\begin{array}{l}\text { Japan, } \\
\text { Korea, } \\
\text { China }\end{array}$ & \\
\hline Aonori & $\begin{array}{l}\text { Monostroma } \\
\text { spp. } \\
\text { Enteromorpha } \\
\text { spp. }\end{array}$ & Green & $\begin{array}{l}\text { 20\% protein; vitamin; mineral; low } \\
\text { fat \& } \mathrm{NaCl} \text {, high } \mathrm{Fe}, \mathrm{Ca}, \mathrm{Mg} \text {; used } \\
\text { for flavoring }\end{array}$ & $\begin{array}{l}\text { Floating system; Rafts. shallow, calm waters; } \\
\text { can be grown in saltwater; 3-4 weeks; }\end{array}$ & $\begin{array}{l}\text { Japan, } \\
\text { Korea }\end{array}$ & \\
\hline Wakame & $\begin{array}{l}\text { Undaria } \\
\text { pinnatifida }\end{array}$ & Brown & $\begin{array}{l}\text { Vitamin B, K; fucoxanthin; Mg, Ca, } \\
\mathrm{Cu}, \mathrm{Co}, \mathrm{Ni}, \mathrm{Zn} \text {; about } 4 \text { calories per } \\
10 \text { g of raw; low levels of fat and } \\
\text { carbohydrates; color can be changed } \\
\text { from brown to green through } \\
\text { heating. }\end{array}$ & $\begin{array}{l}\text { Cultivated on ropes in the open sea rocky } \\
\text { shores; ropes } 10 \mathrm{~m} \text { apart; } 7 \mathrm{~m} \text { down; } 5^{\circ} \text { and } \\
15^{\circ} \mathrm{C} \text {, Mar.-July; plant length can be } 2 \mathrm{~m} \text {; } \\
\text { [Salted: wash in seawater, then freshwater; } \\
\text { initial storage with } 1 / 3^{\text {rd }} \text { wt salted at }-10^{\circ} \mathrm{C} \text { ] }\end{array}$ & $\begin{array}{l}\text { Korea, } \\
\text { Japan }\end{array}$ & \\
\hline Kombu & $\begin{array}{c}\text { Laminaria } \\
\text { japonica }\end{array}$ & $\begin{array}{l}\text { Dark } \\
\text { green }\end{array}$ & $\begin{array}{l}10 \% \text { protein, } 2 \% \text { fat, moderate level } \\
\text { vitamin (A, C); high in iodine; } \\
\text { kombu broth, tea, soup; }\end{array}$ & $\begin{array}{l}\text { Single-, double-raft; buoys } 2-3 \mathrm{~m} \text {; Grows in } \\
\text { 2-15 m deep; } 3^{\circ}-20^{\circ} \mathrm{C} ; 20 \text { mo } \\
\text { growing/harvesting period; } \mathrm{N} \text { and Phosphate } \\
\text { fertilizers; grow 3-10 meters (5-12in wide) in } \\
2 \text { yrs; }\end{array}$ & Japan & \\
\hline Hiziki & $\begin{array}{l}\text { Hizikia } \\
\text { fusiforme }\end{array}$ & Brown & $\begin{array}{l}\text { Similar to Kombu; phlorotannins is } \\
\text { removed before eating; inorganic } \\
\text { arsenic; fibre; } \mathrm{Mg} / \mathrm{Ca}=1 / 2 \text {; }\end{array}$ & $\begin{array}{l}\text { Rocky coastlines; Buoys 2-3 m; water temp } \\
\qquad 20^{\circ} \mathrm{C} \text {; Feb. to June; }\end{array}$ & Korea & \\
\hline
\end{tabular}

\section{Species}

\subsection{Seaweeds}

Not only seaweeds are eaten raw, but through industrial process, some components are extracted to use in other foods. Carrageenan, known as seaweed flour, an extraction of about 25\% of dry Eucheuma seaweed is not only used in the mass customization of ice cream, chocolates, custards, cake topping and fillings, milk shakes, yogurts, dessert gel, canned foods, fish gel, sauces, and many others but also its semi-refined or refined form, is used to manufacture food and drink items, both for human and animal consumption.
Some refined extraction is used to manufacture water paints, toothpastes, lotions, shampoos and several pharmaceutical products. They grow quickly, 10 times heavier in 6 to 8 weeks (Nori grows $1 \mathrm{~cm}$ long takes in one month then the growth is $10-15 \mathrm{~cm}$ long in 15 days), for which the rate of photosynthesis is high. As a result the absorption and release of carbon dioxide and oxygen from the atmosphere are higher compared to other plants, respectively [6].

Because seaweed farming does not require fertilizers, water cleaning, environmental impact is minimal. Besides, China, Japan and Republic of South Korea intensive seaweed growers are also seen in Europe and North America. Table 1 provides 5 types of seaweed species that are very popular. 


\subsection{Fish}

Figure 2 shows the species that are commonly farmed in the world. Species that are produced by aquaculture method are region dependent.

Food and Agriculture Organization (FAO) documentation provides details on species dependent upon the region and climatic conditions. For example, in
Republic of South Korea Undaria and Molluscs dominate the seaweed and fish production, respectively.

Several of the FAO factsheets explain how a variety of aquatic species should be raised in both the hatchery and in grow out ponds and cages.

Information on history, biology, handling and production costs of each species etc. are also available in detailed form $[5,6,7,8]$.

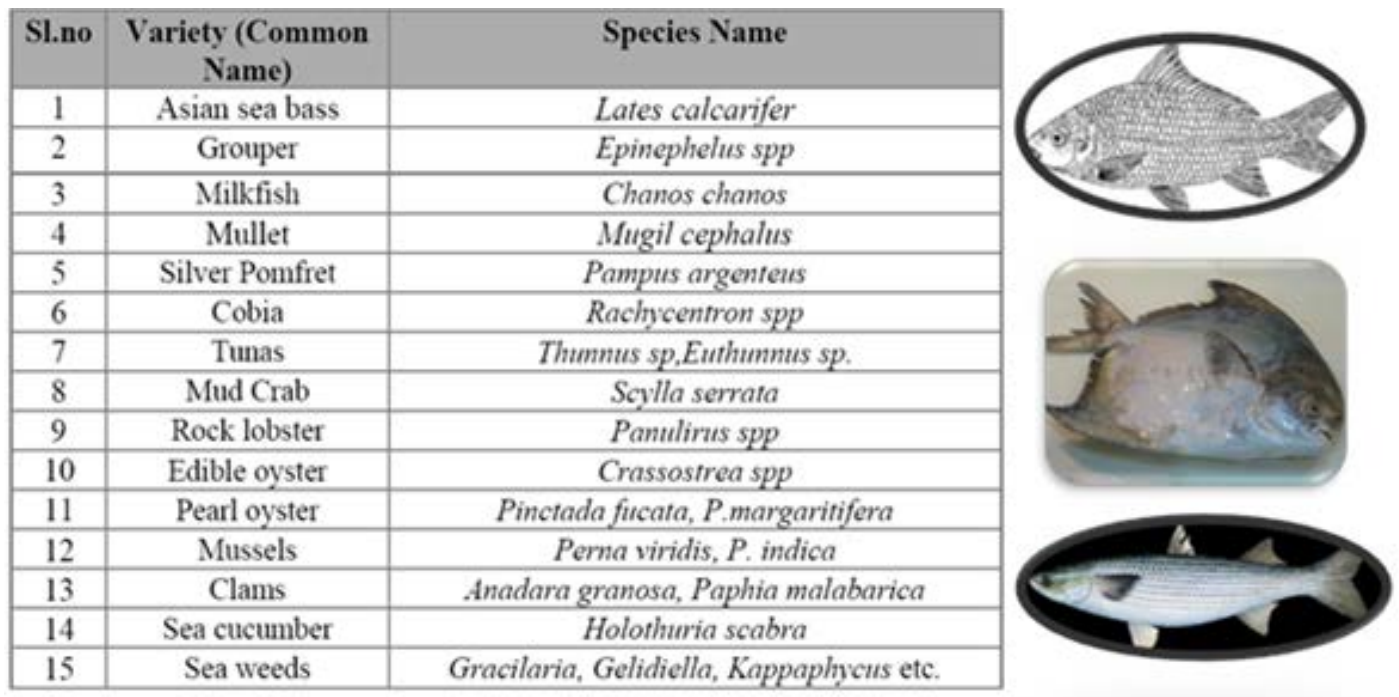

Figure 2. Some species of fish for aquaculture [8]

\section{Advances in Aquaculture Technology}

Successful aquaculture production is measured in terms of economic, social, physical or biological, and sustainability. Seafood supply chain can be divided into two stage operation: farming and post processing. The current aquaculture based seaweed farming does not use any technology system except for post processing areas. Scientific methods and mechanized operations are applied in processing, quality testing, storage, packaging and transportation. On the other hand, the usage of technology is found in the entire operation of aquaculture based fish farming. In what follows is the analysis on cost and suggestions for technology usage in fish farming so that similar methods but different procedure can also be applied in seaweed farming to improve productivity.

Farm production of aquatic species and plants has been constantly expanding with an average annual growth rate of $7.5 \%$. It is the supply-demand curve that inspired the farmers to apply new methods and techniques to produce more seaweed per annum. The technical variations in cultivating seaweeds depends species, local conditions, and experience. For example, the emerging technique such as integrated multi-trophic aquaculture (IMTA) is gaining popularity because of the technique is symbiosis in nature and it eventually meets the demands of users' liking.

Currently, there are no value-added processes introduced to the seafood farming. The farming process includes establishment of the farm, harvesting, replanting, and maintenance. Cleaning, drying, processing, and packing are taken care of by the production unit. Site where production takes place control the quality index and subsequently ship packed bags in containers to advanced countries [9].
A recent review by Diego Valderrama (Diego Valderrama) reports that the production cost per kg of dry seaweed cultivated in the developing, underdeveloped, and Latin American countries such as Philippines, Indonesia, India, Tanzania, Oceania, Mexico is approximately 0.40 cents. The review also revealed that despite low prices, seaweed farming is a profitable venture. In Philippines, more than 116,000 families consisting of more than one million individuals were farming more than 58,000 ha of seaweed. It can be noted that more than $50 \%$ of the seaweed labor force being unskilled and semiskilled $[10,11]$. Enough and affordable manpower to maintain the farms is an indispensable prerequisite. Personnel on all levels of skills play a vital role for overall profitability. A minor error in heuristic based monitoring and regulation of growth cause a significant annual loss for which there can be a threat to this business. The business can improve productivity if technology driven solution to cultivation and production process is geared. By utilizing technology systems, an Indonesian farmer would be able to earn USD 19,140 , four times of the per capita income of the country with an average annual productivity of $1.10 \mathrm{~kg} /$ meter of line producing 33 thousand $\mathrm{kg}$ of dry seaweed on a 10 thousand meter of lines [11,12]. Low-cost technology driven seaweed aquaculture system will significantly improve the productivity in a controlled environment to reduce adverse environmental impact.

Application of technology in seaweed aquaculture has not yet been researched. Even if seaweed farming is not considered a tough job, there are incredible numbers of variables that are managed which sometimes out lie beyond the control of human being. To be productive, the farming should be well attended. This means that farmer constantly visit and check farm 24/7. One of the main factors is that they grow very fast. The minimum water salinity required is about $28 \mathrm{ppt}$. The seaweed needs to be 
kept clean while growing. In order to do this, the farmer has to go to the salt water and shake or raise the seaweed lines to remove any unwanted seaweeds and rubbish, else, the growth and hence the productivity will significantly be reduced. Cleaning is a tedious procedure and vital to seaweed farming. In unclean situation other seaweeds will take away the nutrients necessary for the seaweed of interest causing damage adverse effect growth. Further, some parts of the plant always obstruct the growth of the neighboring plant for which they need to be removed from the platform to shore. Because of ocean currents and other factors, sometimes the cultivating strands (lines) get detached causing loss. These lines should be fastened and lost plants replaced. Yield mapping is important to differentiate quality of seaweed at the cultivation and growing stage. The biggest enemies of seaweeds are fish grazers. Optimal harvesting time is critical to production and should be harvested as soon as it reaches its optimal size. Over-grown plants break and drift away on the sea belt. Also, over matured plants are difficult to dry as their branches are thicker. Onsite determination of optimal growth can be achieved through technology systems that entail continuous monitoring for improved productivity.

Intensive fish farming processes are ongoing in coast and ocean. The objective is to grow fish in a controlled environment. In open ocean the average cage measures 15x15x5 $\mathrm{m}^{3}$ (LWD). Fish species such as milkfish, pompano, seabass, lapulapu and snapper are preferred. However, there are several issues such as pollution and environmental influences. In cage farming, rubbing of fish near cage sides damage fins and tails. As a result a good percentage of fish become sick with various diseases. Also the farming propagates sea lice, parasites and other bacteria which in turn help transfer disease from the wild fish to the aquaculture fish and vice versa. Moreover, the farmer needs to obtain various permits and water-use rights near sea shore because it does belong to public and government. The cage farming is manually operated. Technology will play major role in cultivating seaweeds

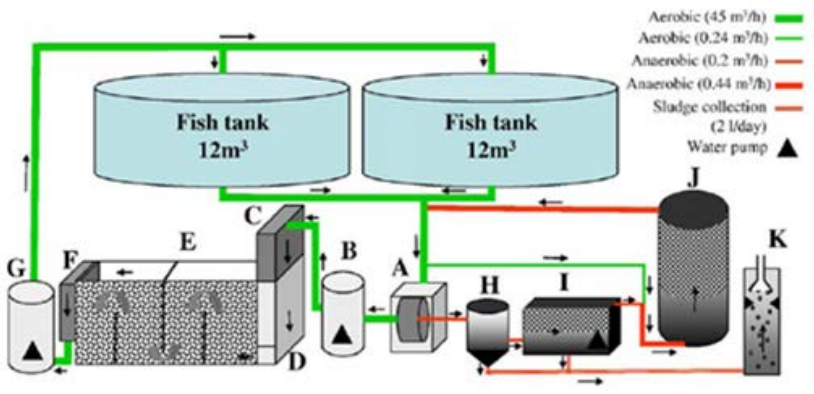

Figure 3. RAS based fish farming - semi-manual (Adopted from Baltimore: Yossi Tal, Harold J. Schreier, Kevin R. Sowers, John D. Stubblefield, Allen R. Place, Yonathan Zohar (2009). Environmentally sustainable land-based marine aquaculture, Aquaculture 286 (2009) 2835

In fish farming implication of technology has already been demonstrated in [13]. The Recirculating Aquaculture System (RAS) developed by team at Baltimore (Figure 3) is a recirculating system integrated with sensors, pumping system and filtering mechanism to measure, control and eradicate parameters, variables, and wastes, respectively. It is an advanced land-based system. It does not have features for calculating growth rate and variable feeding (as the fish grow) and some observations are still manually operated. The other important parameters that are not yet considered for monitoring are disease, agility, nutrients, and sedimentation. Further, the generated biogas byproduct is not being used. Let us formulate a scenario of 10 -storied aquaculture building containing 1000 tanks each has 10 tons of water, $99 \%$ of which need to be recirculated. For such a huge system there is a need of about 20 pumps, 2000 valves, and equivalent feedback control drive systems. There would be 10,000 datalogging (monitoring variables) points to measure $\mathrm{CO} 2, \mathrm{O} 2$, O3, TAS, TAN (Total Ammonia Nitrogen), temperature, $\mathrm{pH}$, light, disease, bacteria, and about 1000 variable feeding system, 250 filter cleaning system, and finally 1000 automation of CO2 strippers and protein skimmers. For such a system, high tech with larger dimension from many fronts is needed. Typical 4-tank based RAS system are presented in Table 2.

Table 2. Specification of a 4-tank based RAS system

Table 2. Specification of a 4-tank based RAS system
\begin{tabular}{|c|c|}
\hline \# Tanks per System: & 4 \\
\hline \% new water makeup/day: & $2 \% \mathrm{gpm} \mathrm{m} / \mathrm{min}$ \\
\hline Culture Tank Volume: & $12 \mathrm{gal} / \mathrm{m}^{3}$ \\
\hline Electrical Supply & $220 \mathrm{~V} / 1 \mathrm{Phase} / 60 \mathrm{~Hz}$. \\
\hline Feed Protein: & $2 \mathrm{mg} / \mathrm{l}$ \\
\hline Max. un-ionized ammonia: & $9 \mathrm{mg} / \mathrm{l}$ \\
\hline Maximum CO2: & $20 \mathrm{lb} / \mathrm{day} \mathrm{kg} / \mathrm{day}$ \\
\hline Maximum Feed Rate: & $75 \mathrm{lbs} / \mathrm{gal} \mathrm{kg} / \mathrm{m}^{3}$ \\
\hline Max.Stocking Density: & $30 \mathrm{mg} / \mathrm{l}$ \\
\hline Maximum TSS: & $5 \mathrm{mg} / \mathrm{l}$ \\
\hline Minimum DO: & City supply, Well \\
\hline Water source: & 7.2 \\
\hline pH: & $25 \mathrm{ppt}$ \\
\hline Salinity: & Seabream \\
\hline Species: & $25^{\circ} \mathrm{C} /{ }^{\circ} \mathrm{F}$ \\
\hline Temperature: & $40 \mathrm{mg} / \mathrm{l}$ \\
\hline Total Ammonia Nitrogen & New / Retrofit \\
\hline Type of installation: &
\end{tabular}

\subsection{Dissolved Oxygen}

Dissolved-oxygen (DO) determines the growth of the fish. Low DO content also harms seaweed. There are several ways to monitor and regulate dissolved oxygen in the water. Further, as water temperature increases, it is less capable of holding $\mathrm{O}_{2}$. For example, at $90^{\circ} \mathrm{F}$ and $45^{\circ}$ $\mathrm{F}$ water holds about $7.4 \mathrm{mg} / \mathrm{L}$ and $11.9 \mathrm{mg} / \mathrm{L}$ of $\mathrm{O}_{2}$. The minimum requirement of DO is about $4 \mathrm{mg} / \mathrm{L}$. Fish may die at less than $2 \mathrm{mg} / \mathrm{L}$. There are two ways to monitor DO: using electronic and chemical test kit probes. Farms monitor DO in the tank or pond at an interval of 2-3 hours especially during night using the probes manually. Aeration system is turned on when the level drops. Note that gas oxygen sensors cannot be used for this type of application. Figure 4 shows several oxygen sensors from various companies and distributors. The one from $\mathrm{HF}$ Scientific, along with other, can connect to a PLC for seamless integration with industrial control systems. It can be interfaced with computer to display data, calibration and customization of the measurement without an intermediate analyzer electronics box. However, DO sensors are relatively expensive. 


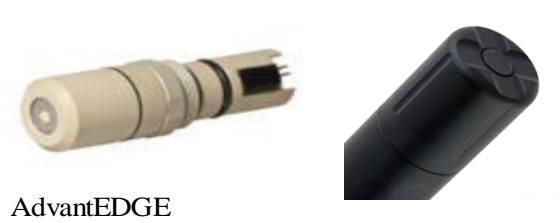

HF Scientific

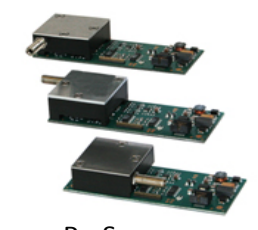

PreSens
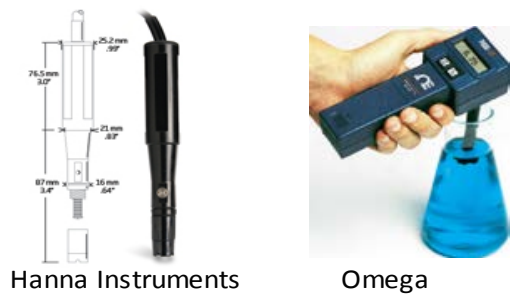

Omega

Figure 4. Sensors used to measure DO

\subsection{Carbon Dioxide}

Fish are immune to 10 ppm of Dissolved carbon dioxide (DCD) provided DO concentration is high. The concentration fluctuates from $0 \mathrm{ppm}$ in the afternoon to 7$12 \mathrm{ppm}$ at dusk. Note that in RAS the concentration should be always higher, sometimes exceeding $20 \mathrm{ppm}$. So, continuous monitoring of DCD is vital because additionally, the high levels interfere with the oxygen utilization by the fish. Aeration techniques works well as the system can blow off the excess gas. The soluble method such as addition of either calcium carbonate or sodium bicarbonate does not work for RAS.

\subsection{Turbidity}

Turbidity is a measure of water clarity. It may not apply to RAS but in fish and seaweed farming ponds it is present. Solid wastes also result primarily from fish faeces and uneaten fish food. It is caused by microscopic algae (phytoplankton), bacteria, dissolved organic substances that stain water, suspended clay particles, and colloidal solids. In pond or marine aquaculture, sediments enter the water from disturbed sites and affect water quality and restrict light penetration and may limit growth. The advantage of turbidity is that phytoplankton turbidity provides DO and fish food organisms although clay and soil turbidity are detrimental. Further, overabundance of phytoplankton can be dangerous. Recirculation method improves the turbidity. The other methods are provision of sumps and settlement tanks, hydro-cyclones using aerators, and use of filters. Total Suspended Solid (TSS) particles can be classified as filterable and colloidal. RAS uses filters to remove the former but not the fine colloidal solids including dissolved waste (0.001-30 micron). The filtration is carried out by two main processes: mechanical filtration and biological filtration. In order to monitor the turbidity, there have been several proposals. The low-cost high tech solution is through image processing tools using computerized camera systems. In order to assess the contrast of fish or seaweed against their background, a measure ranging from light to dark can be used for each image. The color image can be converted to grayscale images representing low dark pixels to high light pixels and be analyzed and interpreted as turbidity after few processing steps which are embedded in the tool. One way of removing the colloidal particle is by the process of ozonation [15]. The exposure standard for residual ozone ranges between 0.05 and $0.1 \mathrm{ppm}$ because this gas is reported to be toxic to a wide range of fish. Ozonation of water prior to the removal of coarse solids is not done because it would be expensive. Continuous monitoring and regulation of ozone is also vital. Ozone can be measured indirectly using oxidation-reduction potential
(ORP) probes. The probe measures the total capacity of an oxidant in a solution to oxidize an electrode that produces a potential difference (voltage) in $\mathrm{mV}$.

\section{Control Architecture}

Control system play important role in aquaculture system. All the measuring and rotating devices must be precisely control to optimize the farming and prost production processes. The control hardware are sensors, motors, pumps, electronics, computer and software as shown in Figure 5.

The control system requires two platforms from automation point of view: device level automation platform (DLAP) and energy level automation platform (ELAP). The DLAP can be used for both fish and seaweed farming. The ELAP is needed if the farming is proposed for open pond based instead of tank-based.

Currently, a dedicated standardized platform which can be used for automating aquaculture operation is not available. However, the existing monitoring and control platforms such as LabView, fieldbus platforms, and other SCADA (Supervisory Control and Data Acquisition) systems can be used. Distributed Control Systems (DCS) concept can be adopted in implementing the monitoring and control architecture. In a centralized design the field devices such as sensors, actuators, another controller, etc. are directly wired back to a physical controller. Status and command signal transfer and all other communications between these field devices and the central controller is established separate links. DCS inherits a concept of networking amongst many controllers instead of one. Because of advancement of electronics and embedded technology, wireless technology can also be integrated. The entire control task of the centralized controller is physically distributed among the low-cost distributed controllers, which are then connected onto a network. The entire system can be thought of as processing of global task in a distributed philosophy using a network-wide protocol. The advantage of the DCS is that it overcomes the fear of central failure and also the problem of costly separate wiring between the field devices.

DCS is seen to be an-effective control architecture in comparison to centralized counterpart. DCS is a proven concept in because of its added advantage such as scalability, configurability, interoperability, modularity, and operational flexibility. Components-based system design can be introduced in the control architecture in order to develop plug-and-play modular system. This approach is suggested because the automated aquaculture system consists of diverse group of devices and components such as electronic and mechanical sensors, switches, power units and drives, electromechanical 
system such as motors, aerator, pump, optical systems, lighting and cable interfaces, and so on. The entire system can be viewed as being built from components. The idea emphasizes that the RAS can be organized as sets of cooperating components rather than as the integration of large custom-built unit. The approach is suitable for the design and building of DCS. The components based DCS architecture for RAS should have external interface to communicate with others via defined user-friendly functions [16].

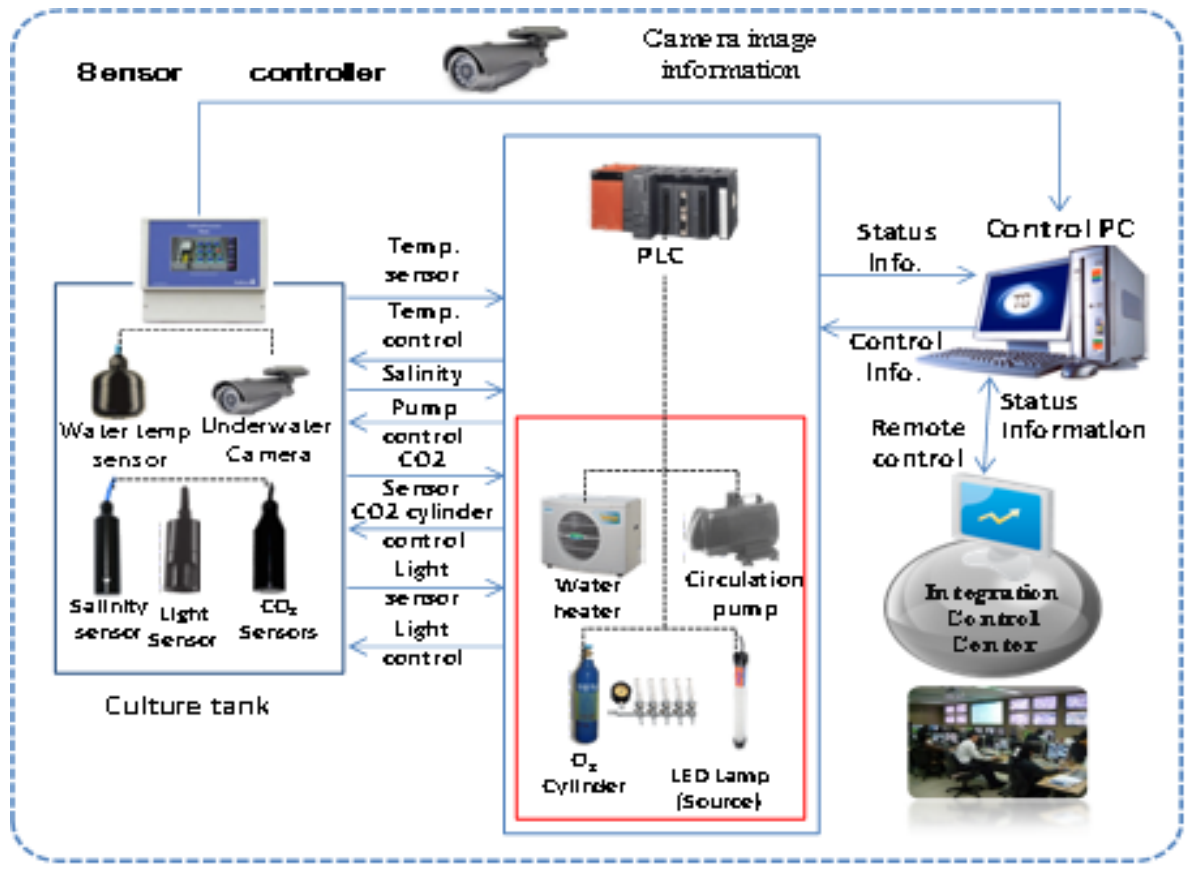

a

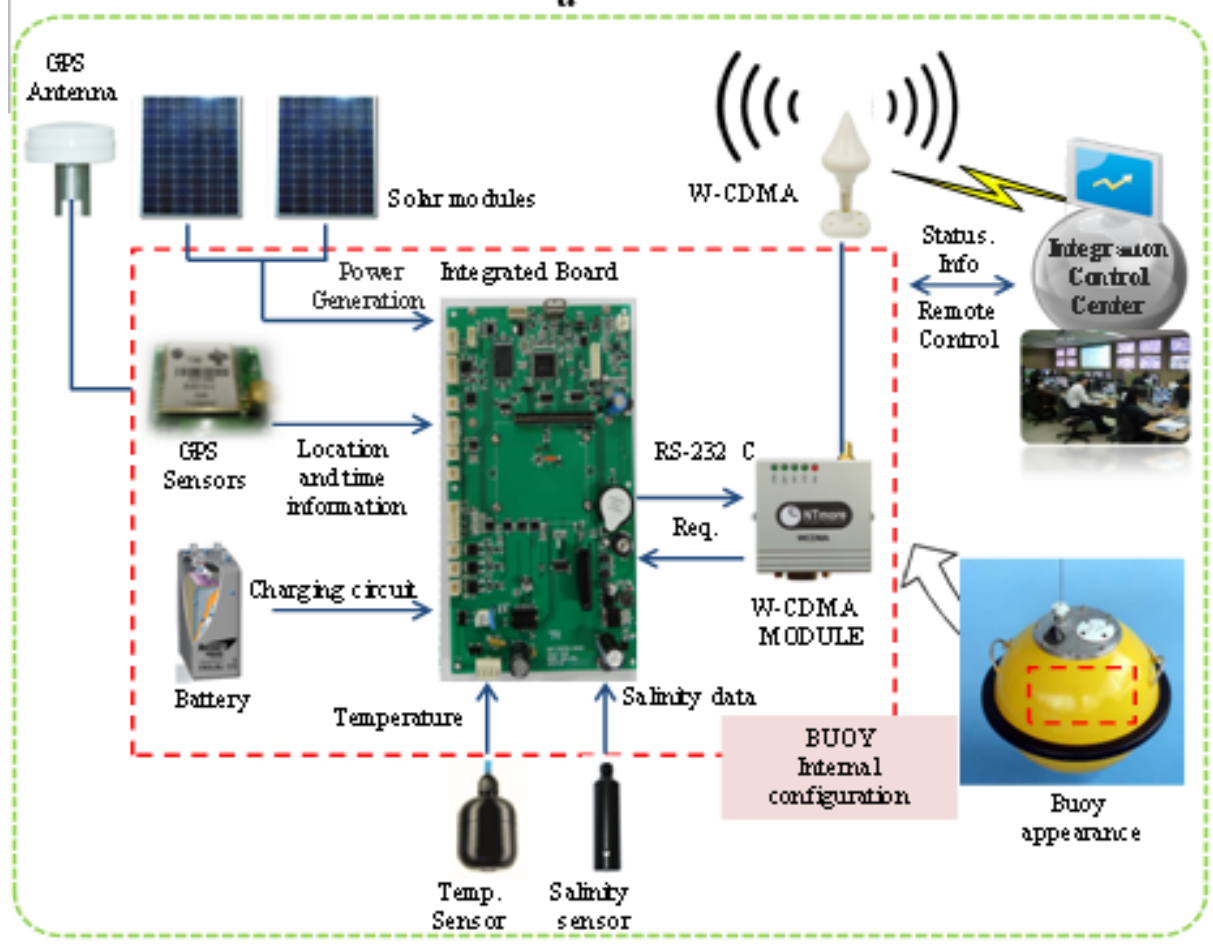

b

Figure 5. (a) DLAP: The scope and extent of technology for a standard model for development, configuration and backup (b) ELAP: Sustainable energy harvesting, floating technology, wireless technology, and control-room management system.

\subsection{A Proposal for Expert System}

The primary cost factor for fish aquaculture can be categorized into three areas such as fixed cost that includes sensors, tank, water, food, pump, valve, and pipes; labor cost; and variable cost that depends on many factors including fish dying rate (the quantity of food consumption will be low, hence the total cost for a production cycle will decrease). In a report it was estimated that the RAS equipment costs should not exceed US $\$ 1.84 / \mathrm{kg}$. About $20 \%$ of investment is fixed cost. The labor productivity, i.e., availability of skilled labor and technical specialists is a factor. The higher wage rates can 
be significantly offset by the use of labor-saving automated technology systems. Cost components also include capital intensity, operating life, feed conversion ratio (FCR), and survival rate. Significant savings can be achieved through variable cost. An expert system utilizing modern technology such as SCADA (Supervisory Control and Data Acquisition), field bus, HMI (Human machine Interface), portable devices (iPOD, iPAD, mobile devices, etc.) is seen as practicable and can also satisfy environmental regulation or enforcement. Such a hightech system has not yet been developed. An expert system could accurately determine the controllable variables. As an example, since FCR determines profit, the automated expert system can automatically calculate and regulate the feed rate. Production per cubic meter affect facilities cost per pound and profit per pound. The expert system can also automatically direct which fish tank to be combined based on fish density due to differential growths (for large system). Similarly, precise control of light (energy), water, $\mathrm{O}_{3}, \mathrm{O}_{2}$, and $\mathrm{pH}$ can save variable cost. Because some cost parameters are influenced by scale of the farm, demandsupply analysis through expert system will be predictive, easy and handy that can substantially eliminate unnecessary costs through heuristic approach. The expert system can be fully-contained with provision for efficient biological waste treatment and water recycling. Some other important parameters to be monitored are temperature, light intensity, fish growth, and traceability. The integrated technology system can be deployed any environment and climate without limiting geographical boundaries. To improve the preventive measures such as marine environmental monitoring, and productivity of new varieties of transplants, collaboration for mass production ensuring stable sales plays a vital role. Further, to establish cost-saving production technologies, transdisciplinary knowledge is important. For example, experts with knowledge on oceanographic buoys, real-time remote communication, industrial process monitoring, and growth analysis are needed. The technology can be proved to be stable and the performance driven

\section{Conclusions}

This paper reviews the developments in aquaculture. Aquaculture based farming are mainly done for fish and seaweed. The trend is that the fish and seaweed that are captured and acquired from the open ocean stays constant since a decade. As a result the aquaculture based farming is gaining momentum because of the demand. Current form of aquaculture is mostly manually operated. Because of scarcity of labor and labor cost, the implication of technology system is considered to be significant. In the second part of the paper we have presented different types of species (both seaweed and fish) that are being aquacultures and also point the reference for the readers. In the third part the paper highlights the role of technology systems, the cost factor analysis, and a proposal for advanced monitoring, control architecture, and an expert system that can be developed to automate the entire aquaculture processes.

\section{Acknowledgement}

The authors acknowledge Department of Industrial Technology, Jordan College of Agricultural Sciences and Technology, Jeollanam-do, Gwangju Institute of Science and Technology, Wando/Jindo, today Fisheries, Fisheries progress, and Guangzhou Regional Meteorological for their time, inputs, and suggestions in different ways.

\section{References}

[1] FAO (Food and Agricultural Organization of United Nations) (2003). Trade Reforms and Food Security, Commodity and Trade Division, Rome.

[2] Lessica Fanzo, Danny Hunter, Teressa Borelli, and Federico Mattei (2013). Diversifying Food and Diets, Bio-diversity International, EarthScan, Routledge.

[3] Food and Agriculture Organization (2010). World fisheries and aquaculture, Fisheries and Aquaculture Department, FAO, United Nations.

[4] Food and Agriculture Organization (2012). World fisheries and aquaculture, Fisheries and Aquaculture Department, FAO, United Nations.

[5] Michel De San (2012). The farming of seaweeds Report/Rapport: SF/2012/28, Report prepared with the assistance of EU.

[6] http://blogs.worldwatch.org/nourishingtheplanet/innovation-ofthe-week-climate-smart-seaweed-farming/

[7] http://www.fao.org/docrep/field/003/ac287e/ac287e01.htm

[8] B. V. Bhat and P. N. Vinod (2008). Development of sea farming in India-an export perspective. In A. Lovatelli, M.J. Phillips, J.R. Arthur and K. Yamamoto (eds). FAO/ NACA Regional Workshop on the Future of Mariculture: a Regional Approach for Responsible Development in the Asia-Pacific Region. Guangzhou, China, 7-11 March 2006. FAO Fisheries Proceedings. No. 11. Rome, FAO. 2008. pp. 301-306.

[9] Dr. Mechthild Kronen, Socio-economic Dimensions of Seaweed Farming in Solomon Islands, Secretariat of the Pacific Community (SPC), Aquaculture Division, Food and Agricultural Organization (FAO) with cooperation with Ministry of Fisheries and Marine Resources, Aquaculture, Honiara, Solomon Islands, January 2010

[10] Cornelia M. Buchholz, Gesche Krause, and Bela H. Buck, Seaweed and Man, Chapter 22, C. Wiencke and K. Bischof (eds.), Seaweed Biology, Ecological Studies 219, \# Springer-Verlag Berlin Heidelberg 2012

[11] Diego Valderrama, Social and economic dimensions of seaweed farming: a global review, Food and Resource Economics Department, University of Florida, USA,

[12] B. Dinghui Zou • Kunshan Gao Zuoxi Ruan, Seasonal pattern of reproduction of Hizikia fusiformis (Sargassaceae, Phaeophyta) from Nanao Island, Shantou, China, J Appl Phycol (2006) 18:195201.

[13] Yossi Tal, Harold J. Schreier, Kevin R. Sowers, John D. Stubblefield, Allen R. Place, Yonathan Zohar (2009) Environmentally sustainable land-based marine aquaculture, Aquaculture 286 (2009) 28-35.

[14] Geoffery J. Meaden and José Aguilar-Manjarrez (Eds.) (2013) Advances in geographic information systems and remote sensing for fisheries and aquaculture, Food and Agricultural Organization (United Nations) Technical Paper, ISSN 2070-701.

[15] Keith Jeffery, Nicholas Stinton \& Tim Ellis (2010). A review of the land-based, warm-water recirculation fish farm sector in England and Wales. Centre for Environment, Fisheries \& Aquaculture Science (Cefas), Weymouth Lab, Barrack Road, The Nothe, Weymouth, Dorset, DT4 8UB. UK.

[16] N. P. Mahalik1 and K. S. Kim (2013). Retrofitting high-tech systems in land-based aquaculture to improve production efficiency: An automated expert system architecture, IETE Technical Review, accepted. 